\title{
Effect of Plant Geometry and Fertilizer Levels on Yield and Economic of Cowpea (Vigna unguiculata L. Walp)
}

\author{
A.R. Jagadale, G.K. Bahure*, I.A.B. Mirza, S.H. Mirche and S.R. Ghungarde \\ College of Agriculture, Latur V.N.M.K.V., Parbhani - 413512, India \\ *Corresponding author
}

\section{A B S T R A C T}

The field investigation entitled "Effect of plant geometry and fertilizer levels on yield and economicsof cowpea (Vignaunguiculata L. Walp)" was conducted at Department of Agronomy, College of Agriculture, Latur. The experimental field was levelled and well drained. The soil was clay loam in texture, low in available nitrogen, very low in available phosphorus, very high in available potassium and moderately alkaline in reaction. The environmental conditions prevailed during experimental period was favourable for normal growth and maturity of cowpea crop. The experimental plot was laid out in a Factorial Randomized Block design (FRBD) with four spacing and three levels of fertilizer which comprises twelve treatment combinations. Each experimental unit was repeated three times. The gross plot size of each experimental unit was $5.4 \times 4.5 \mathrm{~m}^{2}$ and net plot size was $4.8 \times 3.5 \mathrm{~m}^{2}\left(\mathrm{~S}_{1}\right), 4.8 \times 3.6 \mathrm{~m}^{2}\left(\mathrm{~S}_{2}\right), 4.5 \times 13.5 \mathrm{~m}^{2}\left(\mathrm{~S}_{3}\right), 4.5 \times 3.6 \mathrm{~m}^{2}\left(\mathrm{~S}_{4}\right)$ respectively! Sowing was done on $4^{\text {th }}$ July, 2013 with four spacingviz. $30 \times 10 \mathrm{~cm}^{2}\left(\mathrm{~S}_{1}\right), 30 \times 15 \mathrm{~cm}^{2}\left(\mathrm{~S}_{2}\right), 45 \times 10$ $\mathrm{cm}^{2}\left(\mathrm{~S}_{3}\right), 45 \times 15 \mathrm{~cm}^{2}\left(\mathrm{~S}_{4}\right)$ and three levels of fertilizerviz.30:60:00 NPK kg ha ${ }^{-1}, 25: 50: 00$ NPK kg ha ${ }^{-1}$ and 20:40:00 NPK kg ha ${ }^{-1}$ as per treatments. Sowing was done by dibbling method. Cowpea crop grown in kharif season produced significantly higher seed yield, straw yield, gross monetary return, net monetary return and benefit cost ratio of cowpea crop was observed with the wider spacing $45 \times 10 \mathrm{~cm}^{2}$. The higher seed yield, straw yield, gross monetary return, net monetary return and benefit cost ratio was obtained due to higher fertilizer level i.e. application of 30:60:00 NPK kg ha ${ }^{-1}$. The interaction effects of spacing $\mathrm{x}$ fertilizer levels were found non-significant.

\section{Introduction}

The cowpea (Vigna unguiculata L.walp.) belongs to family Leguminaceae with subfamily Papilionaceae. Cowpea is one of the most ancient crops known to man. Its origin and subsequent domestication is associated with pearl millet and sorghum in Africa. It is a broadly adapted and highly variable crop cultivated around the world primarily for seed also as a vegetable, green pods, fresh shelled green peas and dried peas, a cover crop and for fodder. Cowpea is of multipurpose grain legume. The mature cowpea seed contains 24.8 per cent protein, 63.6 per cent carbohydrate, 1.9 per cent fat, 6.3 per cent fiber, 0.00074 percent thiamine, 0.00042 per cent Riboflavin and 0.00281 per cent Niacin (Shaw, 2007). The protein concentration ranges from about 3 to 4 per cent in green leaves, 4 to 5 per cent in immature pods and 25 to 30 percent in mature seeds. It is also rich in source of $\mathrm{Ca}$ and Fe. It is grown as green manure crop for soil 
improvement. Among the grain legumes the green pods of cowpea are used as vegetable. In addition to grain, it also grown for its nutritious fodder, it is also grown as catch crop, mulch crop, intercrop, mixed crop and green crop. It has ability to fix atmospheric nitrogen in soil in association with symbiotic bacteria under favourable condition.

The largest producer is Africa, Brazil, Haiti, India, Myanmar, Srilanka, Australia; Bosnia and Herzegovina also have significant production. Worldwide cowpeas are cultivated in approximate 8 million hectares. The total world production is estimated about 3.3 million tons of dry grain Area under cowpea in India is 3.9 million hectares with a production of 2.21 million tonnes with the national productivity of $683 \mathrm{~kg} \mathrm{ha}^{-1}$ (Singh et al., 2012). Area under cowpea in Maharashtra was 11,800 ha with an average productivity of $400 \mathrm{~kg} \mathrm{ha}^{-1}$ (Anonymous, 2012). Considering this importance of cowpea, Dr. Balasaheb Sawant Konkan Krishi Vidyapeeth Dapoli, has developed and released cowpea variety Konkan Sadabahar which is moderate in yield from 10 to 13 quintal ha ${ }^{-1}$. It is necessary to develop high yielding varieties of cowpea having desirable characters like short maturing period resistance to yellow vein mosaic and pod borer, determinate status, physically and genetically efficient plant type suitable for relatively higher transformation of flower into pods and more importantly the stability in production. Cowpea is called as vegetable meat due to high amount of protein with better biological value on duty weight basis.

There are many reasons for low productivity of cowpea in Maharashtra, Viz., sowing, time, plant population, weed man-agement, insect pest attack, nutrient supply etc. The primary component of cowpea yield is number of pods per plant and weight of individual pod. Number of pods per plant is directly affected by planting density which changes rapidly with the close spacing or with increased seed rate. Thus, yield level can be increased substantially by manipulating certain cultural practices like spacing, seed rate and nutrient supply. Thus adoption of suitable crop geometry will go a long way increasing yield of cowpea. Naim and Jabereldar (2010) reported that, plant density had a significant effect on most of the growth attributes measured. Increasing plant population increased plant height and decreased number of leaves per plant and leaf area index (LAI). Cowpea is a leguminous crop and can fix atmospheric ' $N$ ' with the help of rhizobium bacteria. Deficiency of N, P and K are among major constraints on higher crop productivity in tropical regions. Hence for optimum yield, crop need to be fertilized properly. The recommended dose of fertilizer for cowpea is 25:50 NP kg ha ${ }^{-1}$. Farmers does not follow the recommended dose of fertilizer, they are using low fertilizer level and soil fertility status has deteriorated over the years which resulted in low productivity.

\section{Materials and Methods}

The present field experiment was conducted during kharif season of 2013 at the Experimental Farm, Agronomy Department, College of Agriculture, Latur (Maharashtra). Geographically Latur is situated between $18^{\circ} 05^{\prime}$ to $18^{\circ} 75^{\prime}$ North latitude and between $76^{\circ} 25^{\prime}$ to $77^{\circ} 25^{\prime}$ East longitude its height above mean sea level is about $633.85 \mathrm{~m}$ and has subtropical climate. To study the influence of plant geometry and fertilizer levels on yield and economics of cowpea (Vigna unguiculata L. Walp) under rainfed condition with view to study the response of cowpea to different spacing and levels of fertilizes.

The experimental field was levelled and well drained. The soil of the experimental plot was clayey in texture, low in available nitrogen $\left(225 \mathrm{~kg} \mathrm{ha}^{-1}\right)$, very low in available 
phosphorus (15.82 $\left.\mathrm{kg} \mathrm{ha}^{-1}\right)$, very high in available potassium $\left(526 \mathrm{~kg} \mathrm{ha}^{-1}\right)$. The soil was moderately alkaline in reaction $(\mathrm{pH})$.The environmental conditions prevailed during experimental period were favourable for normal growth and development of cowpea crop. The present experiment was laid out in Factorial Randomized Block Design with three replications. The treatments were consisting of two different factors; one was spacing and other fertilizer. First FactorSpacing (Plant Population): $\mathrm{S}_{1}-30 \mathrm{~cm} \times 10$ $\mathrm{cm}, \mathrm{S}_{2}-30 \mathrm{~cm} \times 15 \mathrm{~cm}, \quad \mathrm{~S}_{3}-45 \mathrm{~cm} \times 10 \mathrm{~cm}$ andS $\mathrm{S}_{4}-45 \mathrm{~cm} \times 15 \mathrm{~cm} \quad$ B) Second factorFertilizer levels: $\mathrm{F}_{1}-80 \%$ RDF (20:40:00 NPK kg ha $\left.{ }^{-1}\right), \mathrm{F}_{2}-100 \% \operatorname{RDF}(25: 50: 00$ NPK $\mathrm{kg} \mathrm{ha}^{-1}$ ) and $\mathrm{F}_{3}-120 \% \operatorname{RDF}(30: 60: 00 \mathrm{NPK}$ $\left.\mathrm{kg} \mathrm{ha}^{-1}\right)$.

The gross plot size of each experimental unit was $5.4 \mathrm{~m} \times 4.5 \mathrm{~m}$ and net plot size $\mathrm{S}_{1}-4.8 \mathrm{~m}$ $\times 3.5 \mathrm{mS}_{2}-4.8 \mathrm{~m} \times 3.6 \mathrm{~m}, \mathrm{~S}_{3}-4.5 \mathrm{~m} \times 3.5 \mathrm{~m}$ and $\mathrm{S}_{4}-4.5 \mathrm{~m} \times 3.6 \mathrm{~m}$ respectively. Pure seed of cowpea Var. Konkan Sadabahar was purchased from Dr. B.S.K.K.V., Dapoli. Cowpea was sown on $4^{\text {th }}$ July 2013. The sowing was done by dibbling with 2-3 seeds per hill at a distance of $30 \times 10 \mathrm{~cm}^{2}, 30 \times 15$ $\mathrm{cm}^{2}, 45 \times 10 \mathrm{~cm}^{2}, 45 \times 15 \mathrm{~cm}^{2}$ at about $5 \mathrm{~cm}$ depth by keeping seed rate $15 \mathrm{~kg} \mathrm{ha}^{-1}$. The object of dibbling was to maintain fairly uniform plant population in each row Gap filling was undertaken 10 days after sowing to maintain optimum plant stand.

Seeds yield of plants from each net plot were harvested and threshed then seeds were cleaned by winnowing and weight of seed per net plot was recorded in $\mathrm{kg}$. Before threshing, weight of sun dried total biological yield from each net plot was recorded. Weight of dried leaves collected from each net plot was also added in biological yield. Then seed weights were subtracted from total biological yield and remaining weights are counted as straw yield in $\mathrm{kg}$.

\section{Results and Discussion}

\section{Effect of spacing}

The wider spacing of $45 \times 10 \mathrm{~cm}^{2}$ recorded significantly higher seed yield $\mathrm{kg} \mathrm{ha}^{-1}$ (1143 $\left.\mathrm{kg} \mathrm{ha}^{-1} 2733 \mathrm{~kg} \mathrm{ha}^{-1}\right)$ straw yield $\left(\mathrm{kg} \mathrm{ha}^{-1}\right)$ was followed by the closer spacing $30 \times 15 \mathrm{~cm}^{2}$ $\left(998 \mathrm{~kg} \mathrm{ha}^{-1}, 2637 \mathrm{~kg} \mathrm{ha}^{-1}\right)$ respectively. This may be happened due to higher plant population in narrow spacing and there was more vegetation and dry matter accumulation was higher resulted in more yields of seed per plant. These results are in conformity with the results of Santiesteban et al., (2002).

The data on gross monetary returns (Rs. ha $\left.{ }^{-1}\right)$, net monetary returns (Rs. ha ${ }^{-1}$ ) and benefit: cost ratio it was revealed that the wider spacing of $45 \times 10 \mathrm{~cm}^{2}$ gave higher gross monetary returns (Rs.69912 ha $^{-1}$ ), net monetary returns (Rs. $47123 \mathrm{ha}^{-1}$ ) and high benefit: cost ratio (2.9). The lowest $\mathrm{B}: \mathrm{C}$ ratio was recorded by narrow spacing $30 \times 15 \mathrm{~cm}^{2}$ (2.6). This may be due to higher economic yield produced by the wider range of spacing and higher plant population $\mathrm{ha}^{-1}$. These results are in conformity with the results of Chhangani (2003).

\section{Effect of fertilizer}

The data on mean seed yield $\left(\mathrm{kg} \mathrm{ha}^{-1}\right)$ and straw yield $\left(\mathrm{kg} \mathrm{ha}^{-1}\right)$ showed that the application of 30:60:00 NPK kg ha-1 recorded highest seed yield and straw yield were 1049 and $2643 \mathrm{~kg} \mathrm{ha}^{-1}$ respectively which was found to be significantly superior over the rest of the fertilizer levels. This can be due to higher growth and yield contributing characters with higher level of fertilizer resulted in higher seed and straw and biological yield. These similar results are conformity with results of Okeleye and Okelana (1997). 
Table.1 Mean seed yield, straw yield, Gross monetary returns, Cost of cultivation, Net monetary returns and Benefit: Cost $(\mathrm{B}: \mathrm{C})$ ratio as influenced by various treatments

\begin{tabular}{|c|c|c|c|c|c|c|}
\hline Treatments & $\begin{array}{c}\text { Seed } \\
\text { yield } \\
\left(\mathrm{kg} \mathrm{ha}^{-1}\right)\end{array}$ & $\begin{array}{c}\text { Straw } \\
\text { yield } \\
\left(\mathrm{kg} \mathrm{ha}^{-1}\right)\end{array}$ & $\begin{array}{c}\text { Gross } \\
\text { monetary } \\
\text { returns } \\
\left(\text { Rs ha }^{-1}\right)\end{array}$ & $\begin{array}{c}\text { Cost of } \\
\text { cultivation } \\
\left(\text { Rs ha }^{-1}\right)\end{array}$ & $\begin{array}{c}\text { Net } \\
\text { monetary } \\
\text { returns } \\
\left(\mathrm{Rs} \mathrm{ha}^{-1}\right)\end{array}$ & $\begin{array}{l}\text { B:C } \\
\text { ratio }\end{array}$ \\
\hline \multicolumn{7}{|l|}{ Spacing $(\mathbf{S})$} \\
\hline$S_{1}-30 \times 10 \mathrm{~cm}^{2}$ & 968 & 2733 & 59268 & 23198 & 35529 & 2.55 \\
\hline $\mathrm{S}_{2}-30 \times 15 \mathrm{~cm}^{2}$ & 998 & 2418 & 61094 & 23512 & 37346 & 2.60 \\
\hline$S_{3}-45 \times 10 \mathrm{~cm}^{2}$ & 1143 & 2637 & 69912 & 24045 & 47123 & 2.91 \\
\hline $\mathrm{S}_{4}-45 \times 15 \mathrm{~cm}^{2}$ & 897 & 2367 & 55192 & 23890 & 32120 & 2.31 \\
\hline S.E. & 17 & 70 & 1071 & - & 1071 & - \\
\hline C.D. at $5 \%$ & 52 & 207 & 3142 & - & 3142 & - \\
\hline \multicolumn{7}{|l|}{ Fertilizer levels (F) } \\
\hline $\mathrm{F}_{1}-20: 40: 00 \mathrm{NPK} \mathrm{kg} \mathrm{ha}{ }^{-1}$ & 967 & 2613 & 59240 & 23580 & 36342 & 2.51 \\
\hline $\mathrm{F}_{2}-25: 50: 00 \mathrm{NPK} \mathrm{kg} \mathrm{ha}^{-1}$ & 987 & 2589 & 60551 & 23792 & 37282 & 2.55 \\
\hline $\mathrm{F}_{3}-30: 60: 00 \mathrm{NPK} \mathrm{kg} \mathrm{ha}^{-1}$ & 1049 & 2643 & 64309 & 24120 & 40465 & 2.67 \\
\hline S.E. & 15 & 61 & 928 & - & 927 & - \\
\hline C.D. at $5 \%$ & 45 & 179 & 2721 & - & 2721 & - \\
\hline \multicolumn{7}{|l|}{ Interaction (S x F) } \\
\hline S.E. & 31 & 122 & 1856 & - & 1856 & - \\
\hline C.D. at $5 \%$ & NS & NS & $\mathrm{NS}$ & - & NS & - \\
\hline General Mean & 1001 & 2549 & 79359 & 24833 & 54526 & 2.57 \\
\hline
\end{tabular}

The data on gross monetary returns $\left(\right.$ Rs. ha $\left.^{-1}\right)$ and net monetary returns (Rs. ha $\left.{ }^{-1}\right)$ and benefit: cost ratio revealed that the application of 30:60:00 NPK $\mathrm{kg} \mathrm{ha}^{1}{ }^{1}$ recorded significantly higher gross monetary returns (Rs.64309 ha $^{-1}$ ), net monetary returns (Rs $40465 \mathrm{ha}^{-1}$ ) and higher benefit: cost ratio (2.67). This might be due to application of higher levels of fertilizer $\left(\mathrm{F}_{3}\right)$ which increased the availability of nutrient resulted in increased yield ultimately increase in gross monetary returns, net monetary returns and benefit: cost ratio. These results are in agreement with the findings of Magani and Kuchinda (2009) (Table 1).

\section{Interaction effect}

The data on gross monetary returns (Rs. ha ${ }^{-1}$ ) and net monetary returns (Rs. ha ${ }^{-1}$ ) was revealed that none of the interaction due to different levels of spacing fertilizer was not influenced significantly.

\section{References}

Anonymous. 2012. FAO Bulletin of Statistics, Statistics Division of Economics and Social Department, 2, 54.

Chhangani, S. 2003. Effect of row spacing of cowpea on growth and green pod yield and weed population in the semi-arid region of Borno State, Nigeria, Department of Crop Science, Faculty of Agriculture, University of Maiduguri, Maiduguri, Nigeria, J. Sustainable Agri. Environ., 5(1): 160-165.

Magani, I.E. and C. Kuchinda. 2009. Effect of phosphorus fertilizer on growth, yield andcrude protein content of cowpea. Vigna unguiculata [L.] Walp. in Nigeria J. Appl. Biosci., 23: 1387-1393. 
Naim, A.M.E. and A. A. Jabereldar. 2010. Effect of Plant density and Cultivar on Growth and Yield of Cowpea. Vigna unguiculata L.Walp. Australian J. Basic and Appl. Sci., 4(8): 3148-3153.

Okeleye, K.A. and M.A.O. Okelana. 1997. Effect of phosphorus fertilization on nodulaion, growth and yield of cowpea. Vigna unguiculata varieties. Indian J. Agri. Sci., 67(1): 10-12.

Santiesteban, S.R., R.A. Zomora, P.E. Gomez, P.P. Verdecia, G.L. Hernandez and Z.W. Zamora. 2002. Effect of sowing density on IITA Precoz [Vignaunguiculata. L). Walp] in two seasons of the year. Alimentaria, 39(332): 45-48.

Shaw, M. 2007. Most Protein Rich Vegetarian Foods Smarter Fitter Blog. http:// smarterfitter.com/ blog/2007.,

Singh, A.K., B.P. Bhatt, P.K. Sundaram, S. Kumar, R.C. Bahrati, N. Chandra and M. Rai. 2012. Study of Site Specific Nutrients Management of Cowpea Seed Production and their Effect on Soil Nutrient Status. J. Agri. Sci., 4(10): 192.

\section{How to cite this article:}

Jagadale, A.R., G.K. Bahure, I.A.B. Mirza, S.H. Mirche and Ghungarde, S.R. 2017. Effect of Plant Geometry and Fertilizer Levels on Yield and Economic of Cowpea (Vigna unguiculata L. Walp). Int.J.Curr.Microbiol.App.Sci. 6(5): 1518-1522. doi: https://doi.org/10.20546/ijcmas.2017.605.165 